\title{
Syriac Language
}

National Cancer Institute

\section{Source}

National Cancer Institute. Syriac Language. NCI Thesaurus. Code C154147.

An Afro-Asiatic language dialect of Middle Aramaic. 